\title{
PENERAPAN AKUNTANSI PERTANGGUNGJAWABAN DALAM MEMPERKUAT HUBUNGAN SISTEM PENGENDALIAN MANAJEMEN DENGAN PENCAPAIAN KINERJA PERUSAHAAN: SUATU TELAAH KEPUSTAKAAN
}

\author{
Karsam \\ karsamse@gmail.com \\ Ruth Leli Ravita Manurung \\ manurung.ruth@gmail.com \\ Universitas Pembangunan Jaya
}

\begin{abstract}
ABSTRAK
Sistem pengendalian manajemen merupakan salah alat untuk mengimplementasikan strategi yang dapat memotivasi seluruh anggota organisasi agar mampu mencapai tujuan. Salah satu karakteristik yang penting dalam menerapkan sistem pengendalian manajemen adalah penerapan akuntansi pertanggungjawaban. Akuntansi pertanggungjawaban mendasarkan pada pemikiran bahwa seorang manajer harus dibebani tanggung jawab atas prestasinya sendiri dan prestasi bawahannya. Pengukuran kinerja dan sistem pengendalian merupakan alat yang digunakan oleh manajer yang efektif dalam mencapai tujuan dan strategi yang diharapkan. Dengan demikian penerapan akuntansi pertanggungjawaban akan memperkuat hubungan diantara sistem pengendalian manajemen dengan pencapaian kinerja.
\end{abstract}

Kata Kunci: akuntansi pertanggungjawaban, sistem pengendalian manajemen, pencapaian kinerja perusahaan.

\section{PENDAHULUAN}

Terdapat banyak faktor yang mempengaruhi kinerja perusahaan diantaranya faktor lingkungan bisnis. Lingkungan bisnis (business environment), dapat dibedakan atas lingkungan eksternal dan lingkungan internal (Wheelen \& Hunger: 2000; 9). Pearce and Robinson (2000:71) membedakan lingkungan bisnis atas lingkungan jauh, lingkungan industri dan lingkungan operasional. Lingkungan eksternal terdiri dari lingkungan makro dan lingkungan industri. Lingkungan internal terdiri dari struktur (structure), budaya (culture), sumber daya (resources) (Wheelen \& Hunger: 2000; 10).

Anthony dan Govindaranjan (2007:3) mengemukakan Sistem Pengendalian Manajemen merupakan alat atau cara yang terstruktur yang digunakan oleh manajer untuk memastikan bahwa orang-orang yang diawasinya mengimplementasikan strategi yang dimaksudkan. Sistem pengendalian manajemen harus didukung dengan struktur organisasi yang baik. Struktur organisasi termanifestasi dalam bentuk struktur pusat pertanggungjawaban (Responsibility centers).

Kinerja menurut Mulyadi (2007: 337) adalah keberhasilan personel, tim, atau unit organisasi dalam mewujudkan sasaran strategik yang telah ditetapkan 
sebelumnya dengan perilaku yang diharapkan. Pengukuran kinerja dapat didefinisikan sebagai proses pengkuantifikasian efisiensi dan efektivitas dari tindakan yang lalu. Ukuran kinerja dapat didefinisikan sebagai sebuah parameter yang digunakan untuk mengkuantifikasi efisiensi dan/atau efektivitas dari tindakan yang lalu. Metrik kinerja adalah definisi dari cakupan, isi dan bagianbagian komponen dari sebuah ukuran kinerja yang berbasis luas (Neely, 2002: xiv). Atkinson, et. Al. (1995) menyatakan pengukuran kinerja sebagai berikut:

"Performance measurement is perhaps the most important, most misunderstood, and most difficult task in management accounting. An effective system of performance measurement containts critical performance indicator (performance measures) that (1) consider each activity and the organization it self from the customer's perspective; (2) evaluate each activity using customer-validated measure of performance; (3) consider all facets of activity performance that affect customers and, therefore, are comprehensive, and; (4) provide feed-back to help organization members identity problems and opportunities for improvement".

Pernyataan diatas mengandung makna bahwa penilaian kinerja sangat penting, kemungkinan memiliki salah pengertian, dan merupakan tugas yang paling sulit dalam akuntansi manajemen. Sistem penilaian kinerja yang efektif sebaiknya mengandung indikator kinerja, yaitu: (1) memperhatikan setiap aktivitas organisasi dan menekankan pada perspektif pelanggan; (2) menilai setiap aktivitas dengan menggunakan alat ukur kinerja yang mengesahkan pelanggan; (3) memperhatikan semua aspek aktivitas kinerja secara komprehensif yang mempengaruhi pelangga dan; (4) menyediakan informasi berupa umpan balik untuk membantu anggota organisasi mengenali permasalahan dan peluang untuk melakukan perbaikan. Lebih jauh Atkinson, Banker, Kaplan dan Young (1995) mengatakan bahwa the role of performance assessment in helping organization members to manage the value chain.

Merujuk pada konsep tersebut, maka penilaian kinerja mengandung tugastugas untuk mengukur berbagai aktivitas tingkat organisasi sehingga menghasilkan informasi umpan balik untuk melakukan perbaikan organisasi. Perbaikan organisasi mengandung makna perbaikan manajemen organisasi yang meliputi: (a) perbaikan perencanaan; (b) perbaikan proses; dan (c) perbaikan evaluasi. Hasil evaluasi selanjutnya merupakan informasi untuk perbaikan "perencanaan-proses-evaluasi” selanjutnya. Proses "perencanaan proses-evaluasi" harus dilakukan secara terus-menerus (continuous process improvement) agar faktor strategik (keunggulan bersaing) dapat tercapai.

Menurut Robert S. Kaplan dan David P. Norton pada tahun 1990 (Thomas umarsan, 2010: 219), dalam sistem pengendalian manajemen dikenal alat analisis yang bertujuan untuk menunjang proses manajemen yang disebut dengan Balanced Scorecard. Menurut Atkinson, et al dalam buku Sony Yuwono, et al (2007: 8), Balanced Scorecard adalah "A measurement and management system that views a business unit's performance from four perspectives:financial, customer, internal business process, and learning and growth".

Sistem pengendalian manajemen ditandai dengan didukungnya tanggung jawab organisasi terhadap para manajer perusahaan. misalnya saja apabila manajemen membutuhkan informasi tentang evaluasi perusahaan, manajer harus dapat memberikan keterangan. Biasanya perusahaan memiliki tingkatan level 
manajer. Sistem pengendalian yang efektif seharusnya juga dapat memotivasi manajer dan karyawan yang berada diperusahaan tersebut. Motivasi tersebut dapat berdampak kepada kinerja perusahaan.

Menurut Anthony Govindarajan (2002:172), Pusat pertanggungjawaban muncul guna mewujudkan satu atau lebih maksud, yang disebut dengan tujuan. Perusahaan secara keseluruhan memiliki tujuan dan manajemen senior menentukan sejumlah strategi untuk mencapai tujuan tersebut. Fungsi dari berbagai pusat tanggungjawab dalam perusahaan adalah untuk mengimplementasikan strategi tersebut. Karena setiap organisasi merupakan sekumpulan pusat tangungjawab, maka jika setiap pusat tanggungjawab telah memenuhi tujuannya, maka tujuan organisasi tersebut juga telah tercapai. Menurut Anthony, Govindarajan (2002:175): Pusat pertanggungjawaban (Responsibility center) adalah suatu unit organisasi yang dipimpin oleh seorang manajer yang bertanggung jawab terhadap aktivitas yang dilakukan. Kegiatannya adalah mengolah masukan (bahan, tenaga kerja atau jasa) menjadi keluaran (barang atau jasa) yang diserahkan kepada pusat pertanggungjawaban yang lain dalam suatu organisasi atau dijual kepada pihak luar yang merupakan penghasilan bagi pusat pertanggungjawaban tersebut.

\section{KAJIAN PUSTAKA}

\section{Akuntansi Pertanggungjawaban}

Akuntansi pertanggungjawaban merupakan salah satu konsep dari akuntansi manajemen dan sistem akuntansi yang dikaitkan dan disesuaikan dengan pusatpusat pertanggungjawaban yang ada dalam organisasi. Istliah akuntansi pertanggungjawaban ini akan mengarah pada proses akuntansi yang melaporkan sampai bagaimana baiknya manajer pusat pertanggungjawaban dapat memanage pekerjaan yang langsung dibawah pengawasannya dan yang merupakan tanggungjawabnya atau suatu sistem yang mengukur rencana dan tindakan dari setiap pusat pertanggungjawaban.

Akuntansi pertanggungjawaban mendasarkan pada pemikiran bahwa seorang manajer harus dibebani tanggung jawab atas prestasinya sendiri dan prestasi bawahannya. Konsep akuntansi pertanggungjawaban menjadi pedoman departemen akuntansi untuk mengumpulkan, mengukur dan melaporkan prestasi sesungguhnya, prestasi yang diharapkan dan selisih yang timbul dalam setiap pusat pertanggungjawaban. Definisi akuntansi pertanggungjawaban menurut Robert N. Anthony dan Vijay Gonvindarajan (1998) : "Sebuah sistem akuntansi yang dirancang bagi sebuah organisasi sedemikian rupa sehingga biaya-biaya dikumpulkan dan dilaporkan sesuai dengan tingkat pertanggungjawaban dalam organisasi. Setiap tingkat pengawasan (supervisory area) dalam organisasi hanya dibebani dengan biaya yang menjadi tanggung jawab dan yang berada dibawah kendalinya."

Sebelum sistem akuntansi pertanggungjawaban disusun, harus lebih dahulu dipelajari garis wewenang dan tanggung jawab pembuatan keputusan sehingga dapat ditentukan pusat-pusat pertanggungjawaban yang ada dalam organisasi. Sistem akuntansi pertanggungjawaban dirancang khusus sesuai dengan struktur organisasi untuk dapat menyajikan laporan-laporan prestasi yang berguna dalam menilai sumbangan manajer tingkat pertanggungjawaban tertentu dalam pencapaian tujuan yang telah ditentukan. 
Akuntansi pertanggungjawaban didasarkan pada premis bahwa semua biaya dapat dikendalikan dan masalah utama yang terjadi adalah sejauh mana rentang pengendalian tersebut. Untuk mengatasi masalah ini maka struktur organisasi dalam suatu perusahaan dibagi menjadi sebuah jaringan pusat-pusat pertanggungjawaban individu, atau sebuah grup dimana fungsi-fungsi yang berhubungan erat mempunyai pimpinan tunggal yang bertanggung jawab atas aktifitas unit tersebut. Beberapa prinsip yang dikemukakan oleh Siegel dan Ramanauskas (1989); (a) Untuk memastikan pertanggungjawaban dan akuntabilitas jaringan berjalan dengan baik maka struktur organisasi dalam suatu perusahaan harus dianalisa secara cermat dan pendapatan / biaya yang benarbenar terjadi harus dapat ditentukan; (b) Untuk menciptakan struktur jaringan pertanggungjawaban yang efisien maka tanggung jawab dan ruang lingkup otoritas dari setiap individu, dari manajemen puncak sampai dengan karyawan paling bawah harus dapat ditentukan secara logis dan jelas.

Menurut Hansen dan Mowen (2005:116), "Pusat pertanggungjawaban merupakan suatu segmen bisnis yang manajernya bertanggung jawab terhadap serangkaian kegiatan-kegiatan tertentu". Dengan pusat pertanggungjawaban maka akan tercipta kondisi di mana rencana yang disusun oleh manajemen dapat terealisir dan mampu mendorong setiap pelaku organisasi untuk bekerja dengan benar dan bertanggung jawab. Sistem ini tidak hanya sekedar menghendaki bahwa organisasi dapat mencapai tujuannya dengan biaya yang efisien, mengarahkan biaya sesuai dengan rencana akan tetapi sekaligus dapat digunakan untuk mengukur prestasi kerja setiap pusat pertanggungjawaban.

\section{Sistem Pengendalian Manajemen}

Menurut Chatered Institute of Management Accounting (1994) secara integrar manajemen dapat difokuskan pada identifikasi, presentasi dan interprestasi informasi yang dapat digunakan untuk: Formulating strategy, Planning and controlling activities, Decision Making, Optimizing the use of resources, Disclosure to shareholders and other external to the entity, Disclosure to employee, Safe guarding assets.

Sistem pengendalian organisasi digunakan untuk memberi motivasi anggota organisasi agar bertindak dan dapat membuat keputusan secara konsisten dengan tujuan organisasi (Leslie Kren, 1997). Dua konsep yang mendominasi penelitian pengendalian organisasi adalah teori perilaku dan teori agensi. Penelitian teori perilaku karyawan menggunakan kerangka dengan menyesuaikan pada perilaku organisasi dan psychology (Parker at al. 1989; Welsch et al, 1988 dalam Leslie Kren, 1997). Penelitian tentang keperilakuan (behavior) sebelumnya hanya menguji hubungan karakteristik sistem pengendalian dan beberapa variabel (misalnya kinerja atau perilaku disfungsional).

Penelitian keperilakuan telah berkembang dengan cepat, dan itu ditandai dengan berkembangnya model kontinjensi organisasi pada perilaku organisasi dan perilaku individu (Fama, 1980). Dalam kenyataannya Copley (1973) dalam J.G. Fisher (1998), menyatakan bahwa pengendalian merupakan hal yang utama pada ilmu manajemen. Perlunya prinsip operasional pada sistem pengendalian manajemen memberikan implikasi bahwa sistem pengendalian yang terbaik dapat memaksimalkan efektivitas manajemen dan merupakan bagian dari kontinjensi. 
Anthony dan Govindaranjan (2007:3) mengemukakan Sistem Pengendalian Manajemen merupakan alat (tools) atau cara yang terstruktur yang digunakan oleh manajer untuk memastikan bahwa orang-orang yang diawasinya mengimplementasikan strategi yang dimaksudkan. Sedangkan menurut Hoque (2004) sistem pengendalian manajemen tidak terbatas pada akuntansi, tetapi juga mencakup konsep pemasaran, komitmen pegawai dan moral, serta desain riset dan pengembangan. Menurut Soobaroyen (2006), Yang dimonitor atau yang diatur dalam sistem pengendalian manajemen adalah kinerja dari perilaku manajer di dalam mengelola perusahaan yang akan dipertanggungjawabkan kepada stakeholders.

Menurut Supriyono (2000:27) sistem pengendalian manajemen adalah sistem yang digunakan oleh manajemen untuk mempengaruhi anggota organisasinya agar melaksanakan strategi dan kebijakan organisasi secara efisien dan efektif dalam rangka mencapai tujuan organisasi, dimana sistem pengendalian manajemen terdiri dari struktur dan proses.

Mulyadi dan Setiawan (2001:3) mendefinisikan sistem pengendalian manajemen sebagai suatu sistem yang digunakan untuk merencanakan berbagai kegiatan perwujudan visi organisasi melalui misi yang telah dipilih dan untuk mengimplementasikan dan memantau pelaksanaan rencana kegiatan tersebut.

Jadi, sistem pengendalian manajemen adalah merupakan suatu sistem yang dirancang untuk menjamin bahwa organisasi telah melaksanakan strateginya secara efektif dan efisien melalui para manajernya. Dua unsur yang penting dalam sistem pengendalian manajemen adalah struktur dan proses sistem pengendalian manajemen.

Struktur merupakan hubungan antara komponen yang dinyatakan dalam bentuk organisasi dan sifat informasi yang mengalir di antara unit-unit tersebut. Komponen-komponen ini saling berkaitan dengan lainnya yang secara bersama-sama membentuk sistem. Setiap komponen dalam struktur memiliki fungsi tertentu untuk mencapai tujuan sistem. Struktur pengendalian manajemen dalam suatu organisasi didasarkan pada tanggungjawab atas jabatannya disebut dengan responsibility centers (pusat-pusat pertanggungjawaban). (Mulyadi, 2001 : 3). Pusat-pusat pertanggungjawaban merupakan bagian-bagian dalam suatu organisasi yang dipimpin oleh seorang manajer yang bertanggung jawab atas aktivitas dalam bagian tersebut.

Menurut Supriyono (2000: 36) terdapat unsur-unsur yang terbagi dalam kelompok struktur yaitu : struktur organisasi, aliran informasi dan pendelegasian wewenang. Proses pengendalian manajemen merupakan seperangkat tindakan yang dilakukan untuk memastikan bahwa organisasi bekerja sesuai dengan tujuan yang melibatkan interaksi dalam sebuah organisasi. Proses pengendalian manajemen yang diukur (Anthony \& Govindarajan, 2005:19) meliputi perencanaan strategis (pemrograman), penyusunan anggaran, pelaksanaan dan evaluasi kinerja.

Perencanaan strategis (pemrograman) dapat diartikan sebagai proses penyusunan program organisasi yang akan dilaksanakan dan menetapkan jumlah sumber daya yang dialokasikan kepada masing-masing program tersebut. Dengan demikian pemrograman yang tepat akan berdampak pada pengelolaan sumber daya perusahaan secara efektif dan efisien. 
Hal kedua dalam proses pengendalian manajemen yaitu penyusunan anggaran. Menurut (Anthony \& Govindarajan, 2005:19) penyusunan anggaran merupakan kegiatan yang berhubungan dengan pengintegrasian programprogram yang sebelumnya bersifat individual ke dalam pusat-pusat pertanggungjawaban. Produk akhir dari proses ini adalah sejumlah biaya pendapatan, laba dan penghasilan yang diharapkan dapat direalisasikan dalam suatu periode anggaran. Dengan demikian bila proses penganggaran berlangsung baik, maka penafsiran biaya pendapatan, laba dan penghasilan yang diharapkan dapat tercapai dengan baik.

Setelah penetapan program dan penganggaran, tahapan selanjutnya adalah pelaksanaan dan pengukuran. Pelaksanaan merupakan implementasi antara rencana dalam bentuk kegiatan maupun biaya. Bila manajemen menginginkan ada kesesuaian antara rencana dengan realisasi, salah satu syarat yang harus dipenuhi adalah konsistensi pelaksanaan dengan rencana baik program maupun penganggaran. Artinya kedua hal tersebut dapat dipedomani dalam melaksanakan kegiatan, bila tidak maka akan terjadi penyimpangan. Sementara itu pengukuran berhubungan dengan penilaian dan pengendalian kegiatan berdasarkan program dan anggaran yang ditetapkan. Selama tahun anggaran, manajer melakukan program atau bagian dari program yang menjadi tanggung jawabnya. Laporan yang dibuat hendaknya menunjukkan dapat menyediakan informasi tentang anggaran dan realisasinya baik itu informasi untuk mengukur kinerja keuangan maupun nonkeuangan, informasi internal maupun eksternal.

Hal terakhir dalam proses pengendalian manajemen adalah evaluasi kinerja. Prestasi kerja bisa dilihat dari efisien atau efektif tidaknya suatu pusat pertanggungjawaban menjalankan tugasnya. Evaluasi dapat dilakukan dengan membandingkan antara realisasi anggaran dengan anggaran yang telah ditetapkan sebelumnya. Evaluasi ini sangat penting dilakukan karena akan berpengaruh terhadap pencapaian hasil suatu prestasi kerja.

Menurut Mulyadi (2001:6) struktur dan proses merupakan dua hal yang membangun sistem pengendalian manajemen. Sistem pengendalian manajemen menyediakan struktur yang memungkinkan proses perencanaan dan implementasi rencana. Dengan demikian dapat dikatakan bahwa sebagai sistem, struktur dan proses sistem pengendalian manajemen keduanya saling berinteraksi, dimana ketercapaian tujuan organisasi dapat tercapai. Salah satu tujuan organisasi yaitu peningkatan kinerja.

\section{Pencapaian kinerja}

Kinerja adalah perilaku anggota organisasi yang mendorong perusahaan dalam mencapai tujuannya (Pierce, et al., 2002: 662). Pengukuran kinerja dan sistem pengendalian merupakan alat yang digunakan oleh manajer yang efektif dalam mencapai tujuan dan strategi yang diharapkan (Simons, 2000: 15). Sistem pengukuran kinerja terdiri dari berbagai teknik yang memungkinkan manajer untuk menyeimbangkan kesenjangan antara: keunggulan, pertumbuhan, dan pengendalian; kinerja jangka pendek dan jangka panjang; harapan pihak lain; dan berbagai motif berbagai perilaku. Pengukuran kinerja yang dilakukan dengan baik dapat digunakan untuk mengatasi kendala organisasi yang menghalangi potensi orang-orang yang berada di organisasi tersebut. 
Kinerja merupakan kondisi yang harus diketahui dan diinformasikan kepada pihak-pihak tertentu untuk mengetahui tingkat pencapaian hasil suatu instansi dihubungkan dengan visi yang diemban suatu organisasi serta mengetahui dampak positif dan negatif suatu kebijakan operasional yang diambil. Kinerja ini dapat dipergunakan manajemen untuk melakukan penilaian secara periodik mengenai efektivitas operasional suatu organisasi, bagian organisasi, dan karyawan berdasarkan sasaran, standar, dan kriteria yang ditetapkan sebelumnya.

Dalam hal ini tentu saja istilah kinerja organisasi melibatkan aspek kemampuan, keterampilan, dan kapabilitas, dan kapasitas. Di sisi lain, istilah kinerja sering juga dikaitkan dengan istilah produktivitas. Tangen (2000:33) menyatakan bahwa banyak orang yang mengklaim bahwa sesungguhnya produktivitas itu merupakan subjek yang lebih luas dari kinerja. Apabila produktivitas itu merupakan konsep spesifik yang berkaitan dengan rasio antara output dan input, kinerja itu merupakan suatu istilah yang melibatkan hampir semua tujuan kompetisi dan keunggulan manufaktur seperti biaya, fleksibilitas, kecepatan, ketergantungan, dan kualitas. Namun, berbagai tujuan kinerja itu bisa memiliki pengaruh yang lebih besar terhadap produktivitas dalam suatu operasi.

Lebih lanjut Tangen (2000:46) mengemukakan bahwa beberapa peneliti dan manajer memandang tujuan kinerja, khususnya kualitas, sebagai suatu bagian dari konsep produktivitas, walaupun sesungguhnya mereka itu hendaknya memandang hal tersebut sebagai faktor yang mempengaruhi produktivitas. Diyakini dalam penelitian ini bahwa kekeliruan sekitar produktivitas ini bahkan akan lebih diruwetkan lagi dengan konsep produktivitas yang terlalu luas. Jika pengukuran produktivitas itu akan memasukkan semua jenis tujuan kinerja, pengukuran itu berada dalam bahaya yang besar untuk menjadi sedemikian rumit sehingga manfaatnya sebagai pengukuran penting dalam peningkatan itu dipertanyakan.

Indikator kinerja secara langsung berkaitan dengan tujuan organisasi (Drucker, 1973; dalam Rowe et al, 1995, 240). Drucker mengemukakan delapan bidang penting dalam penentuan tujuan dan pelaporan pengukuran kinerja, yaitu: Pemasaran, Inovasi, Organisasi Manusia, Sumberdaya Keuangan, Sumberdaya Fisik, Produktivitas, Tanggung Jawab Sosial, Laba.

Konsep pengukuran kinerja dapat dirujuk dari Pyzdek (2000: 213) yang mengartikan pengukuran sebagai penetapan angka-angka untuk mengamati gejala sesuai dengan aturan tertentu. Pendapat lain, adalah dari Gary Siegel dan Helene Ramanauskas-Marconi (dalam Mulyadi, 1993:419) yang mengemukakan bahwa "penilaian kinerja adalah penentuan secara periodik efektivitas operasional suatu organisasi, bagian organisasi, dan karyawannya berdasarkan sasaran, standar, dan kriteria yang telah ditetapkan sebelumnya."

Selanjutnya dikemukakan bahwa penilaian kinerja organisasi merupakan bagian dari manajemen kinerja yang diartikan Doherty and Horne (2002:336) sebagai: "as the process of communicating organizational aims and objectives to all stakeholders, setting performance target in order to measure the achievement of those aims and objectives, and ensuring that all this activity provides the basic for continual improvement". Selanjutnya menurut Doherty and Horne (2002:336) disebutkan ada tiga $\mathrm{E}$ ditambah tiga $\mathrm{E}$ yang lain, yang dapat mengukur kinerja yaitu: efisiensi, efektivitas, ekonomi, serta equity, empati dan ekologis.

Sejalan dengan itu, maka penilaian kinerja sebaiknya mengandung indikator kinerja, yaitu: (1) memperhatikan setiap aktivitas organisasi dan menekankan 
pada perspektif pelanggan; (2) menilai setiap aktivitas dengan menggunakan alat ukur kinerja yang memberikan kesan terhadap pelanggan; (3) memperhatikan semua aspek aktivitas kinerja secara komprehensif yang mempengaruhi pelanggan; dan (4) menyediakan informasi berupa umpan balik untuk membantu anggota organisasi mengenali permasalahan dan peluang untuk melakukan perbaikan.

Merujuk pada batasan di atas, maka penilaian kinerja mengandung tugastugas untuk mengukur berbagai aktivitas tingkat organisasi sehingga menghasilkan informasi umpan balik untuk melakukan perbaikan organisasi. Perbaikan organisasi mengandung makna perbaikan manajemen organisasi yang meliputi; (a) perbaikan perencanaan; (b) perbaikan proses; dan (c) perbaikan evaluasi. Hasil evaluasi selanjutnya merupakan informasi untuk perbaikan "perencanaan-proses-evaluasi" selanjutnya. Proses "perencanaan-proses-evaluasi" harus dilakukan secara terus-menerus (continuous process improvement) agar faktor strategis (keunggulan bersaing) dapat tercapai.

Berkenaan dengan tujuan pengukuran kinerja, Kaplan dan Norton (2000: 128) berpendapat bahwa tujuan dari setiap sistem pengukuran seharusnya adalah untuk memotivasi semua manajer dan pekerja agar melaksanakan strategi organisasi dengan berhasil. Organisasi yang dapat menerjemahkan strategi ke dalam sistem pengukuran akan jauh lebih mampu melaksanakan strategi karena dapat mengkomunikasikan tujuan dan sasarannya. Komunikasi ini memfokuskan manajer dan pekerja kepada berbagai faktor pendorong penting, yang memungkinkan keselarasan investasi, inisiatif, dan tindakan dengan pencapaian tujuan strategis.

Sedangkan menurut Mulyadi (1993: 420) penilaian kinerja dilakukan untuk menekan perilaku yang tidak semestinya dan untuk merangsang dan menegakkan perilaku yang semestinya diinginkan melalui umpan balik hasil, baik yang bersifat intrinsik maupun ekstrinsik.

Menurut Sukarno (2000:178) pengukuran digunakan untuk menilai keberhasilan/kegagalan pelaksanaan kegiatan/program kebijaksanaan sesuai dengan sasaran dan tujuan yang telah ditetapkan dalam rangka mewujudkan misi dan visi organisasi. Pengukuran kinerja mencakup penetapan indikator kinerja dan penetapan capaian indikator kinerja.

\section{PEMBAHASAN}

Penerapan akuntansi pertanggungjawaban dalam memperkuat hubungan sistem pengendalian manajemen dengan pencapaian kinerja

Dalam melaksanakan aktivitas operasionalnya perusahaan diarahkan kepada pencapaian tujuan yang telah ditetapkan sebelumnya. Pada dasarnya, tujuan setiap aktivitas perusahaan adalah untuk mendapatkan keuntungan dengan memaksimalkan penggunaan berbagai sumberdaya yang dimiliki perusahaan. Agar tercipta efisien dan efektifitas dalam penggunaan sumberdaya, maka diperlukan implementasi strategi yaitu diantaranya penempatan/penyusunan struktur organisasi. Adanya struktur organisasi yang baik merupakan alat untuk mengendalikan biaya secara efektif. Struktur organisasi yang baik mengharuskan pembagian wewenang dan tanggungjawab secara wajar serta dapat menempatkan posisi tiap-tiap fungsi pada tempat yang sesuai dalam struktur organisasi, hal ini 
menghindari terjadinya kesenjangan dan tumpang tindih tanggungjawab dan wewenang. (Hano J. Roberts, 1993). Dengan demikian masing-masing pimpinan dalam organisasi mengetahui secara penuh dan tegas apa yang menjadi tanggungjawabnya sehingga memungkinkan dilaksanakannya penilaian pertanggungjawaban atas pelaksanaan kegiatan masing-masing pimpinan.

Casey et. al (2008) menyatakan dalam penelitiannya bahwa penerapan akuntansi pertanggungjawaban sejalan dengan adanya perubahan dalam proses organisasi yang tergantung kepada besarnya organisasi dan ruang lingkup organisasi itu sendiri. Dengan demikian, struktur organisasi harus dirancang sedemikian rupa untuk memudahkan manajemen dalam melaksanakan berbagai aktifitas selain dari upaya mengalokasikan sumberdaya yang dimiliki secara efisien dan efektif. Organisasi perusahaan terdiri atas orang-orang, manajemen harus mencapai tujuannya melalui orang-orang yang ada di organisasi tersebut. Oleh karena itu perusahaan memerlukan adanya desentralisasi, yaitu delegasi otoritas pembuatan keputusan organisasi dengan memberi manajer serangkaian level operasi dan otoritas untuk membuat keputusan yang berkaitan dengan daerah tanggung jawabnya. Suatu organisasi yang terdesentralisasi secara kuat adalah organisasi yang memberikan kebebasan manajer-manajer tingkat yang lebih rendah untuk membuat keputusan.

Sistem pengendalian manajemen merupakan salah alat untuk mengimplementasikan strategi yang dapat memotivasi seluruh anggota organisasi agar mampu mencapai tujuan. Salah satu karakteristik yang penting dalam menerapkan sistem pengendalian manajemen adalah penerapan akuntansi pertanggungjawaban (Baiman, 1982:197). Widener \& Selto (1990), menyatakan bahwa sistem pengendalian manajemen dirancang untuk membantu manajemen dalam merencanakan dan mengendalikan aktivitas organisasi. Anthony (1988) menyatakan bahwa sistem pengendalian manajemen terdiri dari pengendalian manajemen, pengendalian tugas, dan perencanaan strategis.

Demsky \& Sappington (1989) mengungkapkan bahwa akuntansi pertanggungjawaban mempunyai dua aturan luas yaitu; (1) manajer harus dapat dievaluasi berdasar atas apa yang dia kendalikan; (2) pertanggungjawaban mengikuti struktur organisasi, manajer departemen bertanggungjawab atas berbagai aktifitas yang dapat dikendalikan di departemennya. Akuntansi pertanggungjawaban merupakan suatu sistem yang disusun sedemikian rupa sesuai dengan sifat dan kegiatan perusahaan dengan tujuan agar masing-masing unit organisasi dapat mempertanggungjawabkan hasil kegiatan unit yang berada dibawah pengawasannya.

Sri Ayuningtyas (2006:12) menyatakan bahwa akuntansi pertanggungjawaban merupakan sistem akuntansi yang dikaitkan dengan struktur organisasi perusahaan dengan tujuan agar masing-masing unit pertanggungjawaban yang ada dalam organisasi dapat melaporkan dan mempertanggungjawabkan hasil pelaksanaan kegiatan dalam unit/pusat pertanggungjawabannya masing-masing. Pusat pertanggungjawaban merupakan unit organisasi yang dipimpin oleh seorang manajer yang bertanggungjawab atas kinerja unitnya. (Munawir, 2002: 425).

Tepeci (2001) dalam disertasi penelitiannya juga menggunakan budaya organisasi sebagai suatu nilai yang dianut anggota organisasi yang akan mempengaruhi produktivitas individual sebagai anggota organisasi. Rasyid (1998) 
dalam penelitiannya juga memasukkan faktor budaya sebagai variabel utama dalam melihat hubungan saling peran antara akuntansi dan budaya perusahaan dimana akutansi dipraktekan dengan asumsi bahwa akuntansi sebenarnya adalah sebuah artifek budaya, karenanya tidaklah tepat memisahkan keduanya dan kemudian memandangnya sebagai variabelvariabel yang diteliti.

Hasil penelitian Mathieu dan Zajac (1990:171-199) maupun penelitian De Cottis dan Summers (1987:445-470), sama-sama menemukan bahwa komitmen individu terhadap organisasi memiliki hubungan yang positif dengan tingkat performansi kerja. Peni Sawitri (2011) meneliti tentang interaksi Budaya Organisasi dengan Sistem Pengendalian Manajemen terhadap Kinerja Unit Bisnis perusahaan Industri Manufaktur dan Jasa di Indonesia; Hasil penelitian yang dilakukan menunjukkan bahwa budaya organsasi tidak memperkuat hubungan antara atribut dan mekanisme SPM dengan kinerja unit bisnis. Namun penelitian yang dilakukan oleh Achmad Fajar dan Muslim Al-Kautsar (2012) meneliti dengan topik yang sama pada perusahaan BUMN di Bandung menunjukkan hasil bahwa Budaya Organisasi mempengaruhi Sistem Pengendalian Manajemen dan secara signifikan mempengaruhi tingkat kesehatan perusahaan.

Sementara itu penelitian tentang topik Struktur Organisasi dan Sistem pengendalian Manajemen terhadap Kinerja Organisasi telah dilakukan oleh Asri Purnama dan Syaifullah (2013); penelitian dilakukan pada RSUP di Nusa Tenggara Barat yang menunjukkan hasil penelitian bahwa Struktur berpengaruh terhadap Sistem Pengendalian Manajemen dan secara simultan bahawa struktur dan sistem pengendalian manajemen berpengaruh signifikan terhadap kinerja organisasi.

Reni Yustien (2012) dalam penelitiannya dengan topik pengaruh penerapan sistem pengendalian manajemen pada pusat pendapatan dan pusat biaya terhadap kinerja manajerial rumah sakit umum tipe $b$ di provinsi jawa barat; menunjukkan hasil penelitian bahwa; (1) Penerapan struktur pengendalian manajemen berpengaruh positif terhadap proses pengendalian manajemen; (2) Penerapan struktur pengendalian manajemen berpengaruh positif terhadap kinerja manajerial; (3) Penerapan proses pengendalian manajemen berpengaruh positif terhadap kinerja manajerial; dan (4) Penerapan struktur pengendalian manajemen melalui proses pengendalian manajemen berpengaruh positif terhadap kinerja manajerial.

Wulyani \& Wandy Wangi Saputra (2009) meneliti tentang pengaruh kompensasi dan komitmen organisasi terhadap kinerja individual dalam sistem pengendalian manajemen; menunjukkan hasil bahwa Komitmen organisasi berpengaruh positif dan signifikan terhadap kinerja individual dalam sistem pengendalian manajemen. Selanjutnya penelitian Natalia C. Wengko (2013) yang meneliti tentang penerapan akuntansi pertanggungjawaban untuk penilaian kinerja, menemukan bahwa penerapan akuntansi pertanggungajawaban bermanfaat untuk penilaian kinerja perusahaan.

Berdasarkan uraian diatas, dapat disimpulkan bahwa struktur organisasi (desentralisasi) membantu manajemen dalam mendelegasikan berbagai wewenang dan aktifitas kepada manajemen dalam unit/level dibawahnya agar operasional organisasi dapat berjalan secara efektif dan efisien. Penerapan akuntansi 
pertanggungjawaban tidak akan berjalan sebagaimana mestinya secara baik jika tidak diikuti adanya perubahan dalam proses organisasi. (Casey, et. al, 2008). Selanjutnya bagian terpenting dalam sistem pengendalian manajemen adalah adanya penerapan akuntansi pertanggungjawaban (Baiman, 1982:197; Widener \& Selto, 1990). Anthony (1988) menyatakan bahwa sistem pengendalian manajemen terdiri dari pengendalian manajemen, pengendalian tugas, dan perencanaan strategis. Penerapan akuntansi pertanggungjawaban menurut Demsky \& Sappington (1989) harus mampu mengukur kinerja manajer pusat pertanggungjawaban yang didukung adanya struktur organisasi yang baik, sistem pengendalian manajemen dan penerapan akuntansi pertanggungjawaban.

\section{SIMPULAN}

Berdasarkan uraian diatas maka dapat disimpulkan sebagai berikut : (1) Penerapan akuntansi pertanggungjawaban tidak akan berjalan sebagaimana mestinya secara baik jika tidak diikuti adanya perubahan dalam proses organisasi. Struktur organisasi (desentralisasi) membantu manajemen dalam mendelegasikan berbagai wewenang dan aktifitas kepada manajemen dalam unit/level dibawahnya agar operasional organisasi dapat berjalan secara efektif dan efisien; (2) Kinerja organisasi dapat tercapai apabila sistem pengendalian manajemen diterapkan secara memadai. Sistem pengendalian manajemen yang memadai adalah dengan adanya sistem akuntansi pertanggungjawaban.

\section{DAFTAR PUSTAKA}

Anthony, Robert N., Govindarajan Vijay. 2005. "Managemen control system". Irwin : McGraw-Hill.

Aida, Ainul, Mardiyah dan Listianingsih. 2005. "Penerapan Sistem Akuntansi Pertanggungjawaban dan Sistem Pengukuran Kinerja Terhadap Kinerja Manajerial'. Jurnal SNA VIII.

Bernardo Nugroho Yahya, 2002. Jurnal Teknik Industri Universitas Kristen Petra Surabaya "Business Process Reengineering: Concepts, Causes And Effect". Vol. 4 No. 2, Desember, hal. 102-110

Blocher, Edward J., Chen, Kung H., \& Lin, Thomas W., 1999. "Cost Management: A Strategic Emphasis". Mc. Graw-Hill Companies, Inc, USA.

Bryson, John M., 2000. “Perencanaan Strategis bagi Organisasi Sosial”. Yogyakarta Pustaka Pelajar.

Brue, Greg., 2002, “Six Sigma For Managers”, Mc. Graw-Hill Companies, Inc, USA.

Deft, Richard R. 1998. “Organization Theory and Design”, West, New York: West

Hansen and Mowen, 2005, "Akuntansi Manajemen , Jilid dua", dialihbahasakan oleh Ancella A. Hermawan, M.B.A, Jakarta : Erlangga.

Dinda Estika, 2006, "Analisis Pengaruh Perencanaan Strategi Terhadap Kinerja Perusahaan Dalam Upaya Menciptakan Keunggulan Bersaing”, Tesis Program Pascasarjan Universitas Diponegoro 
Gibson, Ivancevich dan Donnelly, 1973, “Organization: Behavior, Structure and Process", Prentice Hall, New Jersey

Greenberg, Jerald \& Baron, Robert. A., 2003, "Behavior in Organizations, Eight Edition", Pearson Education Inc. New Jersey, USA

Hitt, A. Michael, Ireland, R Duane and Hoskisson, Robert E., 2001, "Manajemen Strategis, daya saing dan globalisasi", (Terj), Salemba Empat, Jakarta

Kaplan, R.S. \& Norton, D.P., 1996. "Balanced Scorecard Translating Strategy Into Action ". Boston: Harvard Business School Press.

Kaplan, Robert S., and Saccuzza, Dennis P., 1993, "Psychological Testing (Principles, Application and Issues), $3^{\text {rd }}$ Edition", California : Brooks / Cole Publishing Company

Kenis, I. (1979). Effects of Budgetary Goal Characteristics on Managerial Attitudes and Performance, retrieved at 6 April 2008. From: http://www.jstor.org. The Accounting Review Vol. LIV No. 4. pp 707.

Maman Ukas, 2006, "Manajemen Konsep, Prinsip dan Aplikasi", Bandung: Agnini.

Mulyadi, 2001, “Akuntansi Manajemen”, Yogyakarta : BPFE UGM.

Nazaruddin, Ietje, 1998, Jurnal Riset Akuntansi Indonesia "Pengaruh Desentralisasi dan Karakteristik Informasi Sistem Akuntansi Manajemen terhadap Kinerja Manajerial", Vol 1, No. 2. hal. 141-161.

Primasari, 2002, "Analisis gaya kepemimpinan dan orientasi budaya organisasi terhadap intensitas perencanaan strategik", Tesis Program Pascasarjana Universitas Diponegoro.

Rao, Ashok., Lawrence, Carl P., Dambolena, Ismael, Kopp, Robert J., Martin, John, Farshad, Rafii., Schlesinger, Phyllis F., 1996, "Total Quality Management : A Cross Functional Perspective", John Wiley \& Sons Inc. 